\title{
In-vivo and in-vitro studies on the effects of maternal fasting during embryonic organogenesis in the rat
}

\author{
S. K. L. Ellington \\ Department of Physiology, Downing Street, Cambridge CB2 3EG, U.K.
}

\begin{abstract}
Summary. Pregnant rats were fasted for periods of $6,12,24$ or $36 \mathrm{~h}$ terminating at $10 \frac{1}{2}$ days post coitum (p.c.); virgin rats were fasted concurrently. Both groups showed similar loss of body weight and fall in serum glucose levels. Embryos from rats which were fasted for $12 \mathrm{~h}$ or longer showed retarded growth and differentiation compared with embryos from non-fasted animals. Another group of rats, similarly fasted for periods before $10 \frac{1}{2}$ days p.c. were then fed ad libitum until $15 \frac{1}{2}$ days p.c.; the fetuses were smaller than fetuses of similar age from non-fasted rats.

Embryos from fed mothers were explanted at $9 \frac{1}{2}$ days p.c. and cultured for $45 \mathrm{~h}$ in rat serum prepared from fed or fasted animals. Embryonic development was retarded in the serum from fasted rats unless glucose was added to raise the glucose level to that of normal serum.
\end{abstract}

\section{Introduction}

During periods of starvation mammals rely on their endogenous energy stores for nutrition. The change in the source of energy from exogenous to endogenous supplies in response to starvation is accompanied by changes in metabolic pathways and blood hormone levels. For example, during starvation blood sugar levels fall and fat becomes the principal carbohydrate metabolite, and there are corresponding modifications in the levels of the glycaemic hormones. Under conditions of starvation 'stress' the secretion of adrenocorticotrophic hormone (ACTH) increases and the high ACTH levels in the blood stimulate the secretion of the adrenocorticoid hormones. With depletion of their endogenous fuel supplies animals lose weight.

During pregnancy a mammal has to supply not only its own needs but also those of the developing embryos. The needs of the embryo (or fetus) are greatest during the period of rapid growth shortly before parturition. It has been shown that maternal starvation at this stage of pregnancy causes metabolic changes in the mother similar to those that occur in non-pregnant animals but the changes occur more rapidly in the pregnant animal-a phenomenon termed 'accelerated starvation' (see review by Metzger \& Freinkel, 1975).

The fetal growth of rats is unaffected by periods of maternal starvation of up to $48 \mathrm{~h}$ during the last few days of gestation. However, periods of fasting earlier in pregnancy can affect embryonic development in the mouse. Runner \& Miller (1956) fasted strain 129 mice for 24, 30 or $40 \mathrm{~h}$ starting on the 7 th, $8 \mathrm{th}, 9$ th or 10 th day of gestation and examined the resultant embryos at 19 days p.c. Fasts of 24 or $30 \mathrm{~h}$ caused vertebral and costal deformities and exencephaly; fasts of $40 \mathrm{~h}$ were followed by termination of pregnancy. The incidence of the deformities was highest when maternal mice were fasted on the 9th day p.c. These teratogenic effects of fasting could be almost completely eliminated if fasted mice were given oral supplements of glucose or amino acids. It was not known whether the therapeutic effect was due to a direct effect of the 
raised blood glucose on the embryos or to an indirect effect of the glucose modifying other aspects of the maternal metabolism. Robson \& Sharaf (1952) have shown that in both rats and rabbits high levels of ACTH or cortisol have a deleterious effect on developing fetuses.

This paper describes some of the effects of short periods of maternal fasting in the rat, during mid-gestation, on the mother and the embryos.

\section{Materials and Methods}

Animals and techniques. Female Wistar rats and male CFHB rats were used. Female rats were left with males overnight and those with spermatozoa in the vagina the following morning were regarded as half a day pregnant.

Early in the afternoon rats were anaesthetized in ether vapour, blood was collected from the dorsal aorta, and immediately centrifuged serum was prepared using the method described by Steele (1972). Uterine horns were removed from pregnant rats and the embryos were dissected free from maternal tissue in Hanks solution.

Pregnant animals were fasted for various periods all terminating at 14:00 h on the 11th day of gestation ( $10 \frac{1}{2}$ days p.c.). Water was freely available during the fasting.

Embryo culture. Embryos were cultured in rat serum in rotating glass bottles as described by New, Coppola \& Terry (1973).

Assays. Glucose levels in the serum were assayed using a commercial kit (No. 510, Sigma) for enzymic colorimetric determination of glucose. The protein content of each embryo was determined by the colorimetric method of Lowry, Rosebrough, Farr \& Randall (1951).

\section{Experiments}

(1) Short-term effects of maternal fasting. Pregnant and non-pregnant rats were weighed, isolated and given $200 \mathrm{ml}$ water but no food. After $36,24,12,6$ or $0 \mathrm{~h}$ of fasting they were re-weighed and killed. Blood was collected and serum glucose values were determined. The remaining serum was frozen and used for in-vitro experiments (see Exp. 3).

The uterine horns were removed from the pregnant rats and each decidual swelling was examined; the number of degenerating embryos was recorded. Other embryos were examined in detail; the somites were counted and the degree of axial rotation was noted as dorsally concave posture (U), dorsally convex (fetal) posture (C), or partly rotated (U-C). Any abnormalities were noted and the embryos were then analysed for protein content.

(2) Long-term effects of maternal fasting. Pregnant rats were fasted for 36, 24, 12, 6 or $0 \mathrm{~h}$ before $10 \frac{1}{2}$ days, and were then given food ad libitum until they were killed at $15 \frac{1}{2}$ days $(14: 00 \mathrm{~h})$. Embryos were removed and examined externally for any gross abnormality and the crown-rump lengths were recorded.

(3) In-vitro growth in 'fasted' serum. Embryos were explanted from non-fasted $9 \frac{1}{2}$-day rats and were cultured for $45 \mathrm{~h}$ in serum from pregnant rats which had been fasted for $24,12,6$ or 0 $h$ before being bled at $10 \frac{1}{2}$ days. At the end of the culture embryos were examined to assess the stage of development, and the crown-rump length was measured.

(4) In-vitro growth in 'fasted' serum or 'fasted' serum and glucose. Embryos were explanted from non-fasted $9 \frac{1}{2}$ day pregnant rats and were cultured in serum from $10 \frac{1}{2}$ day pregnant rats for $45 \mathrm{~h}$. The serum was prepared from animals which had been continuously fed or fasted for $36 \mathrm{~h}$. Half the serum from the fasted animals had glucose added to raise the serum glucose level to that of the non-fasted animals $(120 \mathrm{mg} / 100 \mathrm{ml})$.

At the end of culture the embryos were examined to assess the stage of development, and analysed for protein content. 


\section{Results}

Experiment 1: short-term effects of maternal fasting. The effects of periods of fasting in non-pregnant or pregnant rats were compared (Text-fig. 1). The fall in serum glucose (Text-fig. 1a) and the drop in body weight (Text-fig. 1b) with fasting were not notably different in the pregnant and the non-pregnant rats.

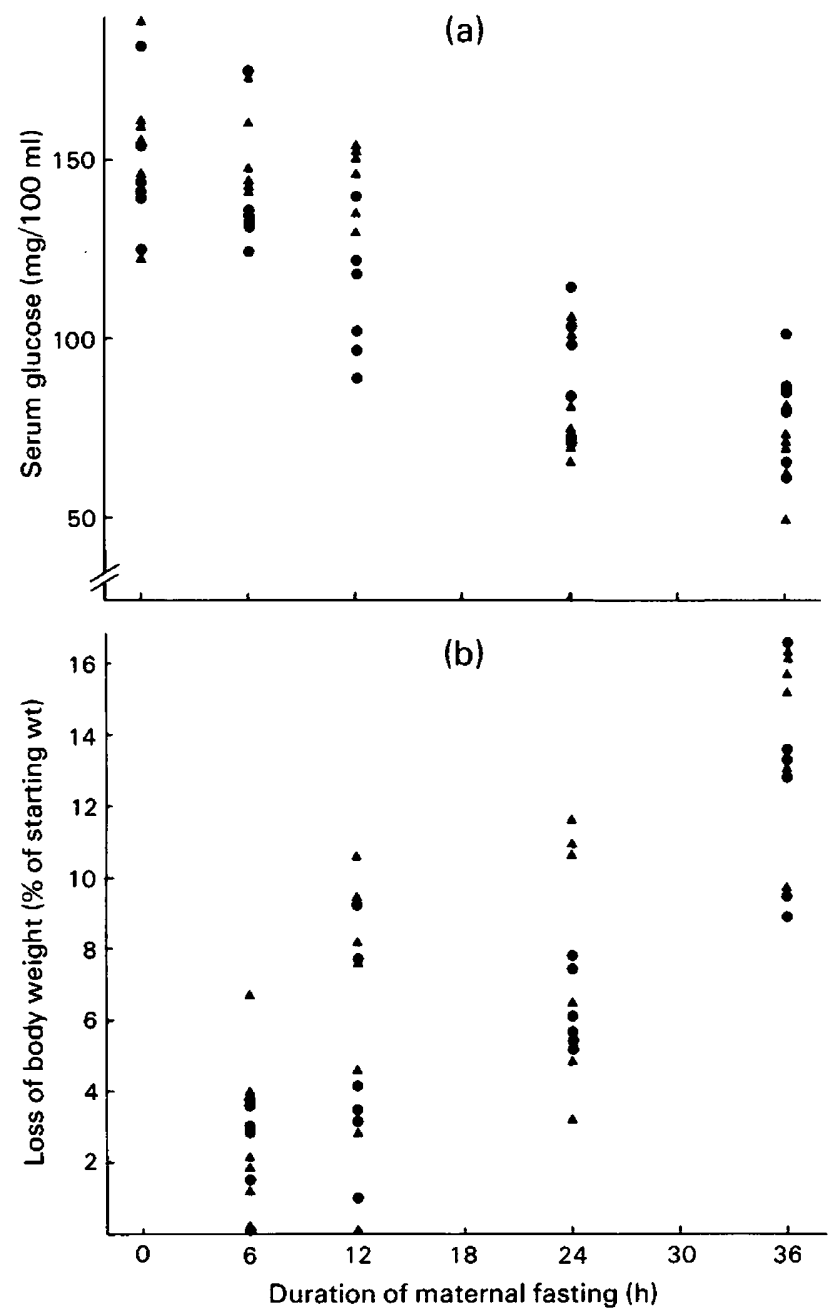

Text-fig. 1. The fall in (a) serum glucose and (b) body weight with periods of fasting in pregnant $(\mathbf{C})$ and virgin $(\Delta)$ rats.

Table 1 summarizes the development of embryos taken from fasted $10 \frac{1}{2}$ day rats. There was a significant retardation of both growth (assessed as protein content of embryo) and development (somite number) of embryos from mothers fasted for $12 \mathrm{~h}$ or longer. There were no differences in the numbers of developing embryos in the fed and fasted mothers. The morphological appearance of the embryos from the fasted rats was consistent with their somite number and crown-rump length rather than their gestational age. No gross abnormalities were noted. 
Table 1. The development of $10 \frac{1}{2}$-day embryos from fed $(0 \mathrm{~h})$ and fasted mothers

\begin{tabular}{ccc}
\hline $\begin{array}{c}\text { Duration of } \\
\text { fasting (h) }\end{array}$ & $\begin{array}{c}\text { Somite } \\
\text { number }\end{array}$ & $\begin{array}{c}\text { Protein content } \\
(\mu \mathrm{g})\end{array}$ \\
\hline 0 & $12.2 \pm 0.2(41)$ & $51.9 \pm 1.7(41)$ \\
6 & $11.7 \pm 0.4(42)$ & $49.1 \pm 1.8(42)$ \\
12 & $* 10.6 \pm 0.4(33)$ & $* 39.6 \pm 2.1(33)$ \\
24 & $* 11.0 \pm 0.2(53)$ & $* 37.5 \pm 1.8(53)$ \\
36 & $* 10.9 \pm 0.3(34)$ & $* 33.7 \pm 1.5(37)$ \\
\hline
\end{tabular}

Values are mean \pm s.e.m. for the no. of embryos indicated in parentheses.

* Significantly different from embryos from fed $(0 \mathrm{~h})$ mothers, $P<0.001$ (Student's $t$ test).

Experiment 2: long-term effects of maternal fasting. At $15 \frac{1}{2}$ days there was no difference between the number of developing fetuses per mother after periods of fasting from 0 to $36 \mathrm{~h}$. None of the fetuses examined had exencephaly or any other noticeable abnormality. Fetuses from mothers fasted for periods of longer than $12 \mathrm{~h}$ were, however, smaller than fetuses from continually fed mothers (Table 2 ).

Table 2. The size of $15 \frac{1}{2}$-day embryos from mothers fasted for different periods up to $10 \frac{1}{2}$ days p.c.

\begin{tabular}{ccc}
\hline $\begin{array}{l}\text { Duration of } \\
\text { fasting (h) }\end{array}$ & $\begin{array}{c}\text { No. of embryos } \\
\text { (no. of mothers) }\end{array}$ & $\begin{array}{c}\text { Mean } \pm \text { s.e.m. } \\
\text { crown-rump length } \\
\text { (mm) }\end{array}$ \\
\hline 0 & $26(2)$ & $12 \cdot 8 \pm 0 \cdot 1$ \\
6 & $24(2)$ & $12.6 \pm 0.1$ \\
12 & $23(2)$ & $* * 12 \cdot 3 \pm 0.1$ \\
24 & $23(2)$ & $* 12.4 \pm 0.1$ \\
36 & $24(2)$ & $* 12.0 \pm 0.1$ \\
\hline
\end{tabular}

Significantly different from values for fed rats $(0 \mathrm{~h})$; ${ }^{*} P<0.01,{ }^{* *} P<0.001$ (Student's $t$ test).

Experiment 3: in-vitro growth in 'fasted' serum. Table 3 summarizes the development of embryos cultured in serum from fed and fasted pregnant rats. Embryos cultured in serum prepared from rats fasted for $12 \mathrm{~h}$ or longer showed retarded growth and differentiation but no other abnormalities.

Table 3. Embryonic development in culture in serum prepared from 'fed' $(0 \mathrm{~h})$ or 'fasted' rats

\begin{tabular}{|c|c|c|c|c|c|c|c|c|}
\hline \multirow{4}{*}{$\begin{array}{c}\text { Duration } \\
\text { of } \\
\text { fasting } \\
\text { (h) }\end{array}$} & \multirow{4}{*}{$\begin{array}{l}\text { No. of } \\
\text { embryos } \\
\text { cultured }\end{array}$} & \multirow{3}{*}{\multicolumn{2}{|c|}{$\frac{\text { Mid-culture }}{\begin{array}{c}\text { Curvature of } \\
\text { embryos }\end{array}}$}} & \multicolumn{5}{|c|}{ End of culture } \\
\hline & & & & \multicolumn{2}{|c|}{ No. of embryos with } & \multirow{3}{*}{$\begin{array}{l}\text { Embryos } \\
\text { fully } \\
\text { rotated } \\
\text { (C) }\end{array}$} & \multicolumn{2}{|c|}{ Mean + s.e.m. } \\
\hline & & & & Heart & Yolk sac & & Somite & Crown-rump \\
\hline & & $\mathrm{U}-\mathrm{C}$ & C & beat & circulation & & number & length (mm) \\
\hline 0 & 9 & 7 & 0 & 9 & 9 & 9 & $24 \cdot 1 \pm 0 \cdot 5$ & $3 \cdot 0 \pm 0.1$ \\
\hline 6 & 8 & 6 & 2 & 8 & 8 & 7 & $22.6 \pm 0.4$ & $3 \cdot 1 \pm 0.1$ \\
\hline 12 & 9 & 3 & 1 & 9 & 9 & 9 & $22.3 \pm 0.7$ & $3.0 \pm 0.1$ \\
\hline 24 & 9 & 3 & 1 & 6 & 6 & 7 & $* * 21.6 \pm 0.7$ & $2.7 \pm 0.1$ \\
\hline
\end{tabular}
$t$ test).

Significantly different from values for embryos cultured in 'fed' $(0 \mathrm{~h})$ serum; ${ }^{*} P<0.05,{ }^{* *} P<0.02$ (Student's 
Experiment 4: in-vitro growth in 'fasted' serum or 'fasted' serum and glucose. Embryos cultured in the serum from rats fasted for $36 \mathrm{~h}$ grew and differentiated less than did embryos cultured in serum from normally fed rats. Addition of glucose to the 'fasted' serum appeared to counteract almost completely the deleterious effect of fasting on embryonic growth in culture (Table 4).

Table 4. Embryonic development in culture in 'fed' or 'fasted' serum with added glucose

\begin{tabular}{|c|c|c|c|c|c|c|}
\hline \multirow[b]{3}{*}{ Serum } & \multirow{2}{*}{\multicolumn{2}{|c|}{ Serum glucose $(\mathrm{mg} / 100 \mathrm{ml})$}} & \multirow{3}{*}{$\begin{array}{l}\text { No. of } \\
\text { embryos }\end{array}$} & \multicolumn{3}{|c|}{ Mean \pm s.e.m. } \\
\hline & & & & \multirow{2}{*}{$\begin{array}{l}\text { Somite } \\
\text { number }\end{array}$} & \multirow{2}{*}{$\begin{array}{l}\text { Crown-rump } \\
\text { length }(\mathrm{mm})\end{array}$} & \multirow{2}{*}{$\begin{array}{c}\text { Protein } \\
\text { content }(\mu \mathrm{g})\end{array}$} \\
\hline & At start & At end & & & & \\
\hline Control ('fed') & 120 & 15 & 20 & $24 \cdot 0 \pm 0 \cdot 3$ & $3 \cdot 1 \pm 0 \cdot 1$ & $227.5 \pm 11.2$ \\
\hline 'Fasted' & 78 & 9 & 20 & $* 22.5 \pm 0.5$ & $* * 2.7 \pm 0.1$ & $* 178.4 \pm 11.2$ \\
\hline 'Fasted' + glucose & 120 & 20 & 20 & $23 \cdot 6 \pm 0.3$ & $2.9 \pm 0.1$ & $211 \cdot 0 \pm 11.0$ \\
\hline
\end{tabular}
$t$ test).

Significantly different from values for embryos cultured in control serum; ${ }^{*} P<0.01,{ }^{* *} P<0.001$ (Student's

\section{Discussion}

Previous work has shown that near-term pregnant rats and women show 'accelerated starvation' in response to periods of fasting (see Herrera, Knopp \& Freinkel, 1969; Freinkel et al., 1972). Such enhanced mobilization of body stores and conservation of essential metabolites probably serve to protect the fetus against temporary maternal food shortages. 'Accelerated starvation'

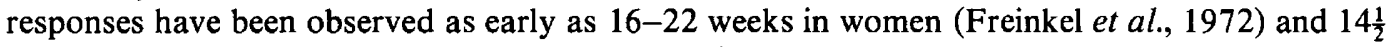
days in the rat (Scow, Chernick \& Brinley, 1964). In the rat the response becomes much more marked as gestation proceeds (Scow et al., 1964).

The present results show that after fasting there are no differences between the rates of weight loss and the fall in serum glucose levels between pregnant rats in mid-gestation and virgin rats of similar size. The 'accelerated starvation' responses shown by animals in late gestation may not therefore be functional during mid-gestation when embryonic organogenesis is occurring.

A lack of adaptive change in the maternal metabolism during embryonic organogenesis probably reflects the relatively small nutritive demands of the developing embryos. In late gestation the 'accelerated starvation' response diminished considerably after hysterectomy and it was suggested that at least some aspects of the response could be induced by the fetal demand for glucose (Scow et al., 1964).

During periods of fasting as maternal blood glucose levels fall and fatty acid levels rise, most of the maternal tissues begin to utilize fatty acid metabolism instead of glycolysis. Late stage fetuses apparently also modify their metabolic pathways to compensate for changes in the maternal metabolism (Girard et al., 1977); fasts of less than $48 \mathrm{~h}$ during the last few days of rat gestation do not affect fetal growth (Scow et al., 1964; Girard et al., 1977). In contrast, during organogenesis in the rat, fasts of $12 \mathrm{~h}$ or longer have a deleterious effect on development. It may be that, at this stage, the embryonic metabolic pathways are not sufficiently developed to enable the embryo to change from glycolysis to fatty acid metabolism. Observations on rat embryos in vitro show that during early organogenesis the embryonic metabolism is characterized by high rates of anaerobic glycolysis (Embden-Meyerhof pathway) and low levels of NADPH oxidase activity (Shepard, Tanimura \& Robkin, 1970).

During organogenesis the allantoic placenta is being formed and the yolk sac placenta is the major site of exchange between mother and embryo. In late gestation the allantoic placenta is the prime site of exchange. Little is known about carbohydrate or lipid transport across the yolk sac 
placenta. It may be that different mechanisms of transport across the two types of placenta contribute to the different responses of mother and embryo to fasting at various stages of gestation.

Rat embryos cultured in 'fasted' serum showed retardation of growth and differentiation compared with those cultured in 'fed' serum. However, when glucose was added to the 'fasted' serum the detrimental effect of fasted serum on embryonic development was very much reduced. Since the same batch of serum was used in the 'fasted' serum culture and the culture in which 'fasted' serum was supplemented with glucose it was assumed that the hormone levels in both cultures were the same. The similarity of the growth of embryos in 'fed' serum and 'fasted' serum with added glucose indicates that low glucose levels, not abnormal hormone levels, are of paramount importance in the deleterious effect of 'fasted' serum on embryonic development in vitro.

I thank Dr D. A. T. New for helpful discussion especially during the preparation of this manuscript and Miss P. A. Blundell for technical assistance. I am grateful to the Medical Research Council for financial support.

\section{References}

Freinkel, N., Metzger, B.E., Nitzan, M., Hare, J.W., Shambaugh, G.E., Marshall, T.R., Surmaczynska, B.Z. \& Nagel, T.C. (1972) "Accelerated starvation" and mechanisms for the conservation of maternal nitrogen during pregnancy. Israel J. med. Sci. 8, $426-439$.

Girard, J.R., Ferré, P., Gilbert, M., Kervran, A., Assan, R. \& Marliss, E.B. (1977) Fetal metabolic response to maternal fasting in the rat. Am. J. Physiol. 232, E456-E463.

Herrera, E., Knopp, R.H. \& Freinkel, N. (1969) Carbohydrate metabolism in pregnancy. VI. Plasma fuels, insulin, liver composition, gluconeogenesis, and nitrogen metabolism during late gestation in the fed and fasted rat. J. clin. Invest. 48, 2260-2272.

Lowry, O.H., Rosebrough, N.J., Farr, A.L. \& Randall, R.J. (1951) Protein measurement with the Folin phenol reagent. J. biol. Chem. 193, 265-275.

Metzger, B.E. \& Freinkel, N. (1975) Regulation of maternal protein metabolism and gluconeogenesis in the fasted state. In Early Diabetes in Early Life, pp.
303-311. Eds R. A. Camerini-Davalos \& H. S. Cole. Academic Press, New York.

New, D.A.T., Coppola, P.T. \& Terry, S. (1973) Culture of explanted rat embryos in rotating tubes. J. Reprod. Fert. 35, 135-138.

Robson, J.M. \& Sharaf, A.A. (1952) Effect of adrenocorticotrophic hormone (ACTH) and cortisone on pregnancy. J. Physiol., Lond. 116, 236-243.

Runner, M.N. \& Miller, J.R. (1956) Congenital deformity in the mouse as a consequence of fasting. Anat. Rec. 124, 437-438, Abstr.

Scow, R.O., Chernick, S.S. \& Brinley, M.S. (1964) Hyperlipemia and ketosis in the pregnant rat. $A m$. $J$. Physiol. 206, 796-804.

Shepard, T.H., Tanimura, T. \& Robkin, M.A. (1970) Energy metabolism in early mammalian embryos. Devl Biol., Suppl. 4, 42-58.

Steele, C.E. (1972) Improved development of 'rat egg-cylinders' in vitro as a result of fusion of the heart primordia. Nature, Lond. 237, 150-151.

Received 22 February 1980 